\title{
The Role of Bacteria in the Pathogenesis of Inflammatory Bowel Disease
}

\author{
Melissa Friswell, Barry Campbell, and Jonathan Rhodes \\ Gastroenterology Research Unit, University of Liverpool School of Clinical Sciences, Liverpool, UK
}

Crohn's disease (CD) and ulcerative colitis (UC) have features that suggest bacterial involvement, and all genetic models of inflammatory bowel disease (IBD) require the presence of commensal bacteria. $C D$ is associated with innate immune response genes such as NOD2/CARD15 and the autophagy genes ATG16L1 and IRGM. However, IBD responds to immunosuppression, suggesting that any bacteria involved are not acting as conventional pathogens. Molecular techniques are rapidly advancing our knowledge of the gut microbiota. In CD there is reduced diversity, and notably a reduction in the probiotic Faecalibacterium prausnitzii, the presence of which in the terminal ileum is associated with a reduced risk of recurrence following surgery. There is also a consistent increase in mucosa-associated Escherichia coli with an "adherent and invasive" phenotype, which allows them to replicate inside macrophages and induce granulomas. Speculation that CD could be caused by the Mycobacterium avium subspecies paratuberculosis (MAP) continues. The response to antitumor necrosis factor treatments suggests that, if relevant at all, MAP is not acting as a conventional pathogen. However, there is increased colonization by MAP in CD, and there is evidence that it could have an indirect effect mediated by the suppression of macrophage function. UC relapse is frequently associated with infection by pathogens, but there is less evidence for involvement of a specific bacterial species. Poor barrier integrity followed by an inflammatory reaction to bacterial components, with chronicity maintained by an autoimmune process, seems a plausible pathogenic model. Bacterial theories of pathogenesis are now becoming testable by targeted therapeutic interventions. (Gut
Liver 2010;4:295-306)

Key Words: Inflammatory bowel disease; Ulcerative colitis; Crohn; Bacteria; Escherichia coli

\section{FAECAL BACTERIA IN INFLAMMATORY BOWEL DISEASE: CROHN'S DISEASE IS ASSOCIATED WITH REDUCED DIVERSITY AND REDUCED FAECALIBACTERIUM PRAUSNITZII}

Studies on faecal samples using modern molecular techniques have allowed a much more complete picture to be obtained than can be achieved by reliance on culture. Such studies have shown that Crohn's disease (CD) faecal samples have a marked reduction in diversity. In healthy individuals, $95 \%$ of the bacteria in stool samples belong to the bacteroides, Clostridium coccoides and Clostridium leptum subgroups ${ }^{1}$ however, inflammatory bowel disease (IBD) patients showed a marked reduction in numbers of these organisms, including bifidobacteria but, in particular, a reduced content of bacteria in the C. leptum subgroup of the firmicutes phylum. ${ }^{2}$ Particular interest is currently focussed on one member of this group: Faecalibacterium prausnitzii. A very strong association has been shown between ileal $\mathrm{CD}$ and lack of $F$. prausnitzii. This holds up whether samples are taken from the terminal ileum or other sites in the colon. ${ }^{3}$ Some studies have shown an apparently reciprocal relationship with E. coli. ${ }^{3}$ Interestingly, dysbiosis in infectious colitis is also characterised by a decrease in organisms that include $F$. prausnitzii. ${ }^{4}$ The mechanism of the apparent probiotic effect of F. prausnit-

\footnotetext{
Correspondence to: Jonathan Rhodes

Department of Gastroenterology \& Nutrition, Institute of Translational Medicine, University of Liverpool, Nuffield Bldg., Crown Street, Liverpool, L69 3GE, UK

Tel: +44(0)151-7946829, Fax: +44(0)151-7946825, E-mail: rhodesjm@liverpool.ac.uk
}

Received on February 10, 2010. Accepted on April 6, 2010.

DOI: $10.5009 / \mathrm{gnl} .2010 .4 .3 .295$ 
$z i i$ is not yet known. Generation of butyrate from unabsorbed fibre is one possible explanation but $F$. prausnit$z i i$ also has directly anti-inflammatory properties. The $F$. prausnitzii supernatant has no direct bactericidal effect on other bacteria. ${ }^{2}$ Secreted metabolites from F. prausnitzii block NF $\kappa \mathrm{B}$ activation and reduce IL8 secretion from Caco2 cells. In addition, peripheral blood monocytes express increased anti-inflammatory IL10 and reduced pro-inflammatory IL12 in the presence of $F$. prausnitzii and IFN $\gamma$. Mice with 2,4,6-trinitrobenzenesulfonic acid (TNBS)induced colitis treated by gavage with $F$. prausnitzii or its culture supernatant show a reduced activity of colitis that is paralleled by a decrease in the pro-inflammatory cytokine IL12 and an increase in anti-inflammatory IL10.

An increase in fungal communities in biopsy and faecal samples from Crohn's disease patients has also been reported. ${ }^{5}$ This shift in diversity may be secondary to changes observed in bacterial communities ${ }^{5}$ but high dietary concentrations of fungal organisms have been shown to augment intestinal inflammation in IBD. ${ }^{5}$ The presence of circulating antibodies to Saccharomyces cerevisae (Baker's yeast) in about two thirds of Crohn's patients is particularly intriguing. It needs to be noted though that the epitope for anti-Saccharomyces cerevisiae antibody (ASCA) is a mannan (with a mannose $\alpha 1,3$ mannose linkage) that is expressed by various organisms, including Candida albicans and Mycobacterium paratuberculosis. ${ }^{6}$

\section{MUCOSA-ASSOCIATED BACTERIA}

The mucosa and overlying mucus represents a unique environmental niche and it has become recognised that the bacteria within this niche may be very different from those in the faecal stream. Studies that have cultured the colonic mucosa after removal of overlying mucus have shown that the mucosa in healthy individuals is relatively sterile but that there is a marked increase in bacteria in Crohn's disease, and to a lesser extent in ulcerative colitis (UC) ${ }^{7,8}$ E. coli seem to account for a relatively high proportion of these mucosa-associated isolates, perhaps reflecting that their microaerophilic properties are suited to living in a mucosal niche that probably has a considerably higher oxygen tension than the faecal stream.

\section{E. COLI}

E. coli is the most numerically dominant Gram negative species of the healthy gastrointestinal microbiota. ${ }^{9}$ The link between E. coli and IBD was first suggested in 1978 by Tabaqchali et al. ${ }^{10}$ who noted that high titres of antibodies against $E$. coli O-antigens were commonly observed in IBD patients. However, E. coli bearing conventional markers of pathogenicity were detected very infrequently and thought unlikely to play a significant role in the

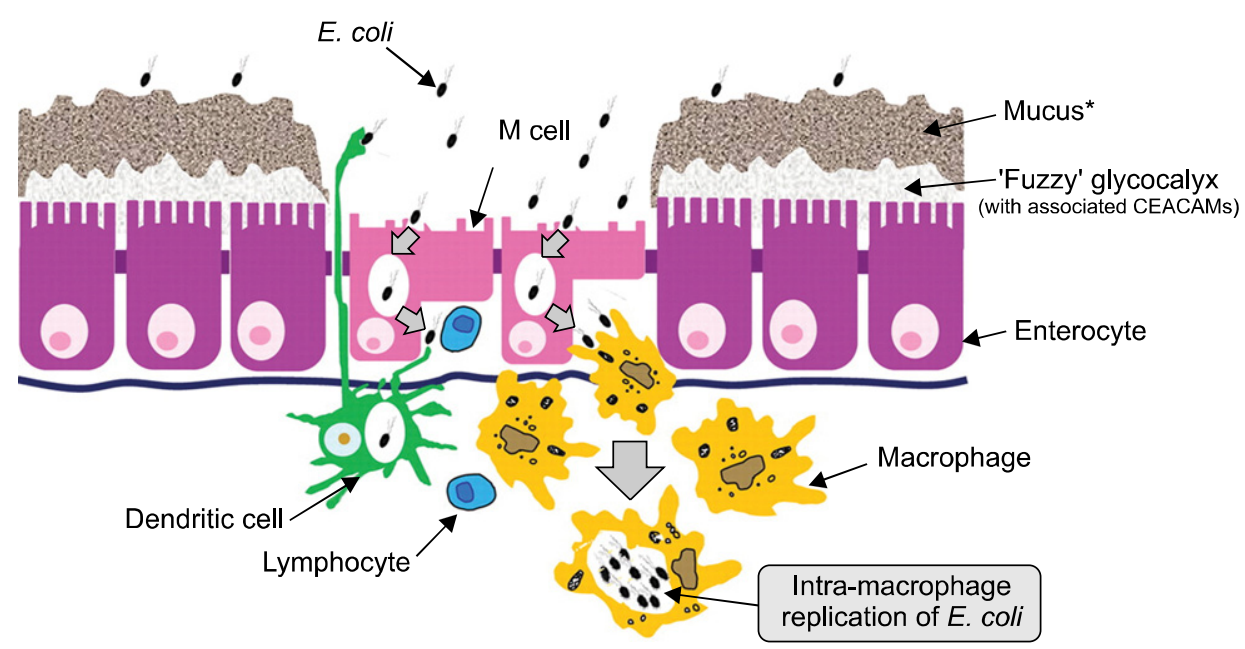

Fig. 1. Bacteria-epithelia interaction (reproduced with permission from Knight $\mathrm{P}$, et al. Br Med Bull $\left.2008 ; 88: 95-113^{126}\right)$. It is likely that the portal of entry of E. coli commonly isolated from inflammatory bowel disease patients is through specialized microfold "M" cells that exist within the follicle-associated epithelium (FAE). Both the absence of overlying mucus (there are no goblet cells in the FAE) and the diminished glycocalyx present on $\mathrm{M}$ cells facilitates interaction with the luminal contents, and thus antigen sampling. E. coli are also shown replicating within macrophages. Dendritic cells participate, possibly by direct sampling of bacteria from the lumen, but also by receipt of bacteria from $\mathrm{M}$ cells. Not to scale: the mucus layer, at $>100 \mu \mathrm{m}$, is considerably thicker than the glycocalyx, at $<1 \mu \mathrm{m}$. 
pathogenesis of IBD. ${ }^{11}$

A key study in 1998 demonstrated that E. coli were isolated in increased numbers from the mucosa of $\mathrm{CD}$ patients, showed an increased ability to adhere to gastrointestinal epithelial cells, and had the ability to potentially disrupt the intestinal barrier by producing an alpha haemolysin. ${ }^{12}$ Furthermore, these E. coli invaded and survived inside epithelial cells in a way similar to that of salmonella (Fig. 1). ${ }^{13}$ A new pathotype was proposed to describe these E. coli: "adhesive and invasive E. coli" (AIEC). It was shown by PCR that one of the more invasive AIEC isolates, LF82, did not possess any virulence characteristics normally associated with enteroinvasive (EIEC), enteropathogenic (EPEC) or enterotoxigenic (ETEC) E. coli. Further investigations on AIEC have revealed that they stimulate the release of the pro-inflammatory cytokine IL-8, ${ }^{7,14}$ and preferentially belong to phylogenetic groups B2 and D. ${ }^{15}$ LF82 has been shown to replicate extensively in macrophages ${ }^{16}$ and deletion of $y f g l$ and $N l p l$ lipoprotein encoding genes, reduce its invasive ability. ${ }^{17,18}$ AIEC have been shown to be associated with granulomatous colitis in boxer dogs. ${ }^{19}$ Importantly, macrophages infected with AIEC express TNF- $\alpha$ and transform in vitro into granulomas. $^{20,21}$ No specific genotype has yet been identified which correlates closely with the AIEC phenotype.

Serological studies have also demonstrated the presence of antibodies to a range of bacteria, including, but not exclusively, E. coli, in human IBD. Studies in mice suggest that the overwhelming majority of anti-bacterial antibodies are directed against bacterial flagellin. Moreover when flagellin-specific CD4 $(+)$ cells were introduced into naive SCID mice, severe colitis was induced. Increased concentrations of circulating IgG antibodies to flagellins are found in patients with CD but not UC or controls. ${ }^{22}$

\section{THE M CELL AS A PORTAL OF ENTRY}

There is good evidence that even bona fide pathogens such as shigella, cholera, mycobacteria and listeria are only able to penetrate the mammalian intestine by first entering through the microfold (M) cells that make up about $5 \%$ of the epithelial cells in the dome epithelium that overlies Peyer's patches in the intestine and lymphoid follicles in the colon. ${ }^{23,24}$ It seems highly likely then that the AIEC found in Crohn's disease lesions have also entered by this route. This is supported by evidence that the initial lesions of Crohn's disease, the aphthoid ulcers, also occur at the site of Peyer's patches and colonic lymphoid follicles. ${ }^{25-27}$

$M$ cells derive from epithelial cells by interaction with underlying B lymphocytes in a process that is not yet well understood. They have the unique ability to sample antigens from the gastrointestinal lumen before presenting them to both dendritic cells and lymphocytes ${ }^{28}$ and thus play an important role in mucosal immunity. $M$ cells are distinct from other intestinal enterocytes in that they have a poorly organised apical brush border with short, irregular microvilli. ${ }^{29} \mathrm{M}$ cells have very little glycocalyx and the dome epithelium in which they exist is devoid of goblet cells and thus has no overlying mucus layer thus ensuring that $M$ cells have optimal access to luminal antigens. ${ }^{30} \mathrm{M}$ cells increase in number in response to bacterial challenge, indicating that the antigen sampling mechanism within the gut is able to be rapidly up-regulated. $^{31,32}$

$\mathrm{M}$ cells are able to transport a wide range of microorganisms, including bacteria, ${ }^{30,33,34}$ viruses ${ }^{35,36}$ and parasites. $^{37}$ Macrophage migration inhibitory factor (MIF) plays an important role in the regulation of the M-cell mediated bacterial uptake in the gut. ${ }^{38}$ Salmonella spp., Shigella spp. and Yersinia spp. have been shown to invade and destroy $M$ cells and spread to neighbouring enterocytes $^{23}$ although not all invading organisms are cytotoxic to $M$ cells. Thus $M$ cells are important not only in the development of the mucosal immune response, but also as a portal of entry for infectious diseases. Certain bacterial genetic factors such as the long polar fimbriae of salmonellae play an important role in determining the organisms' ability to adhere to $M$ cells. Variation in this and similar genetic determinants may explain differences in the ability of enteropathogens to adhere to $\mathrm{M}$ cells. Thus, the rabbit diarrheagenic E. coli (RDEC)-1 strain adheres to $M$ cells $^{24,32}$ whereas although enterohemorrhagic E. coli (EHEC) were seen to attach to the FAE, specificity for $\mathrm{M}$ cells could not be proven. ${ }^{39}$ Furthermore EPEC are not trancytosed by the $\mathrm{M}$ cells. The entry of $\mathrm{M}$ cells by intestinal pathogens is also mediated by surface adhesion molecules, in particular those within the integrin family. ${ }^{40-44}$

It has recently been shown that organisms such as $E$. coli and salmonellae that express the FimH protein of type 1 pili bind to $M$ cells by interaction between FimH and glycoprotein 2 (GP2) expressed on the apical plasma membrane of $\mathrm{M}$ cells and that possession of FimH is essential to allow invasion of $\mathrm{M}$ cells by these organisms. ${ }^{45}$ By an intriguing coincidence it has also recently been found that the same GP2 protein is the epitope for the "anti-pancreatic" antibody found in Crohn's disease sera. ${ }^{46}$ This raises the possibility that a combination of bacterial components, including FimH, linked to GP2, may be presented as a foreign antigen and thus lead to development of anti-GP2 antibodies in a way analogous to the develop- 
ment of anti-tissue transglutaminase antibodies in celiac disease.

Blockade of bacterial entry via $M$ cells represents an important potential target for therapies and more research is urgently needed to elucidate the molecular mechanisms of interaction between bacteria and $\mathrm{M}$ cells. Promising new techniques that involve the co-culture of bacteria and epithelial cell monolayers ${ }^{47}$ and the use of Ussing chambers to allow short term culture of human epithelium containing Peyer's patches ${ }^{48,49}$ may shed light on these interactions.

\section{REPLICATION OF AIEC WITHIN MACRO- PHAGES}

Within the gastrointestinal tract, neutrophils normally serve as the first line of defence against pathogenic bacteria. ${ }^{50}$ In CD however, there is evidence of neutrophil dysfunction; particularly reduced neutrophil accumulation, seen experimentally as a consequence of diminished IL8 production after biopsy trauma to the rectum and ileum ${ }^{51}$ and after subcutaneous injection of killed E. coli. ${ }^{52}$ If neutrophils, the "professional" killers of bacteria, fail to clear invading bacteria, it is left to macrophages, which are intrinsically weaker killers of bacteria, to "clear up." The presence of bacteria within macrophages initiates an inflammatory cascade which can either eliminate the organism, or if the organism survives, lead to higher levels of invasion ${ }^{53}$ or result in the formation of granulomas. The advantage of invasion and replication to the bacteria may be two fold. Firstly, if the invading organisms are not killed by the macrophages they may be able to reside and replicate in the macrophages undetected by the immune system. Secondly, when internalised by macrophages, the bacteria become inaccessible to neutrophils.

In keeping with this, E. coli have been observed within macrophages and giant cells in the tissue of CD patients using immunohistochemistry and PCR techniques. In an immunohistochemical study, $57 \%$ of tissue samples from CD patients were shown to contain E. coli. The organism was found near to ulcers, along fissures, around abscesses, within the lamina propria, and in the germinal centres of mesenteric lymph nodes. ${ }^{54}$ In a study using PCR after laser capture microscopy E. coli DNA was found in $80 \%$ of granulomas from CD tissue. ${ }^{55}$

In vitro studies have shown that the AIEC isolated from Crohn's disease patients are particularly able to survive and replicate in macrophages. ${ }^{16,56}$ They can be seen within double membrane vesicles, implying that they are able to survive within autophagosomes. Further research is needed to understand how they evade killing by the macrophages.

\section{EFFICACY OF ANTIBIOTICS}

Given the strong evidence for bacterial involvement in the pathology of Crohn's disease, it is logical that antibiotics might be therapeutic. When interpreting the results of clinical trials it needs to be remembered that some antibiotics may have effects on the innate immune system, thus metronidazole has been shown to reduce neutrophil recruitment. ${ }^{57}$ Antibiotic therapy for $\mathrm{CD}$ has been used to target mycobacterial infection and more broadly to target aerobes, anaerobes, Gram positive and negative bacteria. ${ }^{57-59}$ Combination antibiotic therapy targeting Mycobacterium avium subspecies paratuberculosis showed a modest initial effect that was not sustained. ${ }^{60}$ Rahimi et al. $^{61}$ conducted a meta-analysis of randomised placebo-controlled trials covering a total of 804 patients with active $\mathrm{CD}$, and concluded that those receiving antibiotics, particularly metronidazole, ciprofloxacin and cotrimoxazole, were 2.3 times more likely to show clinical improvement compared with placebo.

It is important to identify the target for the antibiotics. If AIEC replicating within macrophages are the most appropriate target then antibiotics that do not penetrate macrophages will clearly be ineffective. Studies in our laboratory concluded that azithromycin, ciprofloxacin, rifampicin, sulfamethoxazole, tetracycline and trimethoprim were all effective against $E$. coli within macrophages. ${ }^{56}$

Use of single antibiotics is likely to be unsuccessful in Crohn's disease because of the development of bacterial resistance. Thus a controlled trial showed that clarithromycin as a single agent was apparently effective for one month but then lost efficacy by the principal endpoint at 3 months. ${ }^{62}$ Clinical trials of antibiotic combinations in $\mathrm{CD}$ patients are currently ongoing. There is of course a possibility that antibiotics may increase the overgrowth of pathogenic organisms such as C. difficile. ${ }^{63}$

\section{EFFECTS OF DIETARY COMPONENTS ON THE MICROBIOTA}

There has been considerable interest in the potential use of dietary modification in treating and preventing IBD, particularly CD. Diet can have a substantial impact on microbial communities within the gastrointestinal tract. Prebiotics, which typically include fibre components, selectively promote growth of "beneficial" commensal organisms. The concept that dietary constituents may be used to prevent bacterial disease is not new. Over 30 years ago Aronson et al. ${ }^{64}$ demonstrated that the applica- 
Table 1. Dietary Carbohydrates That Have Been Shown to Inhibit Bacterial Binding to GIT Epithelial Cells

\begin{tabular}{llll}
\hline \multicolumn{1}{c}{ Organisms targeted } & \multicolumn{1}{c}{ Animal, site of infection } & \multicolumn{1}{c}{ Inhibitor } & Reference \\
\hline C. jejuni & Mouse GTI & Milk oligosaccharide & 127 \\
E. coli & Mouse GIT & Mannose & 128 \\
& Calf GIT & Glycopeptides & 129,132 \\
Salmonella enterica serovar Typhimurium & Human GIT (epithelial cells) & Bovine MUC1 & 131 \\
Helicobacter pylori & Human GIT (epithelial cells) & Bovine MUC1 & 131 \\
& Piglet GIT & Sialyl-3'LacNac & 132 \\
& Monkey GIT & Sialyl-3'Lac & \\
\hline
\end{tabular}

GIT, gastrointestinal tract.

tion of methyl alpha-D-mannopyranoside to mouse bladder prevented the colonisation of mouse bladder by $E$. coli. Since then, dietary components have been shown to be useful in treating not only bacteruria, but also gastric bacterial infections-including salmonellae ${ }^{65,66}$ and Helicobacter pylori. ${ }^{67}$

Soluble carbohydrates in dietary components may be recognised by bacterial lectins because of their structural similarity to glycolipid or glycoprotein receptors. Extracts from boiled green bananas have been shown to improve clinical severity of childhood Shigellosis, ${ }^{66}$ and other childhood bacterial infections. A number of carbohydrates have been shown to specifically inhibit bacterial binding to epithelia in vivo and in vitro (Table 1).

Work by our own group has shown that the soluble fibre from edible plantains (Musa sp) prevent adherence to the epithelium by $E$. coli isolated from IBD patients. ${ }^{7,68}$ Interestingly, in cultures where plantain consumption is high (Africa, India, and the West Indies), the prevalence of IBD is rare. We are currently conducting clinical trials investigating the use of soluble plantain fibre in the maintenance of remission in Crohn's disease.

\section{MYCOBACTERIUM AVIUM SUBSPECIES PARA- TUBERCULOSIS AND CROHN'S DISEASE}

Mycobacterium avium subspecies paratuberculosis is an obligate pathogenic organism, that is the causative agent of Johne's disease in cattle. ${ }^{69}$ The link between Crohn's disease and Mycobacterium avium subspecies paratuberculosis (MAP) was first postulated by Dalziel in 1913, even before Crohn's classic description of the disease, when he noted the similarities with Johne's disease, an intestinal disorder of ruminants which bears many of the hallmarks of $\mathrm{CD}^{70}$ Studies since then have shown very contradictory findings but the consensus is that MAP is present in a significant minority of Crohn's disease tissue samples, perhaps particularly within granulomas. ${ }^{71}$

MAP is notoriously difficult to culture although modern techniques have improved its culture from intestinal tissue, milk and blood. ${ }^{72}$ MAP has been cultured from blood in up to $50 \%$ of $\mathrm{CD}$ patients and $22 \%$ of UC patients ${ }^{73}$ but no control patients, similarly, punch biopsies harboured MAP in $42 \%$ of CD patients and $9 \%$ of controls ${ }^{74}$ however other centres have failed to culture the organism. Detection of MAP using PCR is generally preferred because of the shorter time scale and the increased sensitivity of the technique. Early PCR methods have been questioned because of the similarity of the primers for MAP to other non-MAP-mycobacterium-which leads to false positives. ${ }^{75}$ Recent advances have led to the design of a nested IS900 PCR method, which provides more reliable results and has eliminated early concerns over using PCR for detection of MAP in CD patients. ${ }^{74,76}$ The IS900 region is only present in MAP, and has 15-18 copies per genome. The first primer set targets a 413 bp region within the IS900 area in the MAP genome, the second set of primers then targets a $333 \mathrm{bp}$ section within the previously amplified DNA. ${ }^{76}$ This technique ensures that there is almost no chance of obtaining false positive results. The nested PCR technique has proved to be popular and accurate, with recent studies using this method to identify MAP in IBD patients more frequently than in control patients. ${ }^{77,78}$ Another recent study using the nested IS900 PCR method demonstrated the presence of MAP DNA in children with $\mathrm{CD}$ at early onset, ${ }^{79}$ which is the earliest identification of MAP DNA in a patient to date. There have now been several studies that have shown the presence of MAP DNA in adult blood samples ${ }^{73,80,81}$ and in diseased tissue. ${ }^{80}$

An alternative way to study the link between MAP CD patients is to assess whether the patient has MAP antibodies that react to MAP antigens. Meta-analyses have shown that p35 and p36 antigens are reactive to CD patient sera ${ }^{82}$ however it is worth noting that MAP p35 and p36 are similar to that of $M$. avium subspecies. avium (MAA), so a specific reaction to MAP rather than MAA cannot be certain. ${ }^{83}$ 
Further evidence to suggest a link between MAP and $\mathrm{CD}$ includes the increased presence of MAP-reactive $\mathrm{T}$ cells in CD and their absence in control patients. ${ }^{84}$ The same study demonstrated that $\mathrm{T}$ cells isolated from $\mathrm{CD}$ patients were extremely reactive to MAP, more so that $B$. thetaiotaomicron, L. gasseri, B. bifidum and E. coli; additionally, these $\mathrm{T}$ cells produced the pro inflammatory cytokines INF $\gamma$ and IL17. ${ }^{84}$ Basler et al. ${ }^{85}$ have demonstrated that in contrast to MAA and M. avium subspecies hominissuis (MAH), which cause mycobacteriosis in animals and immunocompromised humans, MAP infection causes the reduced expression of 17 genes in a macrophage model when compared to MAA infected cells. Of the differentially expressed genes, six were pro-inflammatory factors (IL-1beta, IL-1alpha, CXCL2, PTGS2 [COX2], lipocalin [LCN2] and TNF) demonstrating that infection of murine macrophages with MAP causes the suppression of pro-inflammatory mechanisms-increasing the chances of the organisms survival in vivo. Other studies have shown that MAP isolated from humans (MAPh) had markedly different protein expression than MAP isolated from cattle (MAPc). MAPh showed higher expression of six proteins when compared to MAPc, the two proteins that showed highest expression were; PepA and ModD. PepA is a serine protease whereas ModD is a fibronectin attachment protein that is necessary for the internalisation and invasion of epithelial cells by MAP, which is likely to confer an advantage to MAP when causing infection. ${ }^{86}$

CD patients show increased levels of ASCA, ${ }^{87,88}$ the epitope for which is a mannose with a specific mannose $\alpha$ 1-3 mannose terminal disaccharide ${ }^{89,90}$ which is present in yeast walls, Candida albicans, ${ }^{91}$ Mycobacterium bovis and Mycobacterium chelonae. ${ }^{92,93}$ Yeasts are large and are likely to be visible in the tissue of CD patients, therefore an alternative source of cell wall mannans.is likely. Studies by our group demonstrated not only that MAP is a possible source for the ASCA mannan epitope, but also that MAP releases a mannose-containing glycoconjugate that impairs the in vitro ability of monocyte-derived macrophages to kill phagocytosed E. coli. Thus MAP might be acting via an indirect pathogenic effect and its lack of direct pathogenicity might explain how it might have a role in pathogenesis and yet not be greatly exacerbated by anti-TNF treatments. $^{6}$

In addition to possible microbial and immune factors, Crohn's disease is associated with genetic mutations (Fig. 2) encoding various homeostatic mechanisms, including, innate pattern recognition receptors (NOD2/CARD15, TLR4, CARD9); autophagy (ATG16L1, IRGM, LRRK2); differentiation of lymphocytes (IL-23R, JAK2, STAT3, CCR6, ICOSLG) and the organisation of immune func-

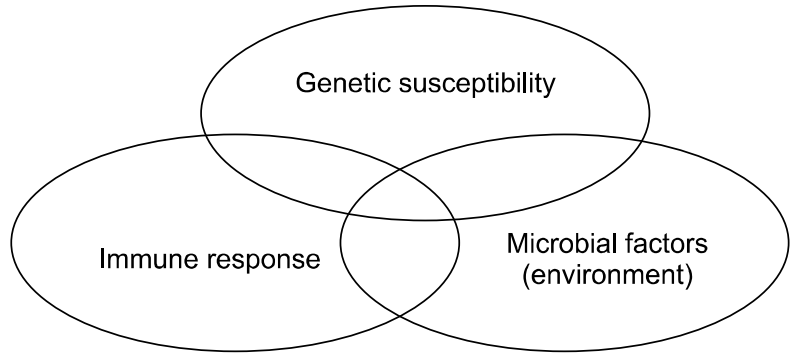

Fig. 2. Pathogenesis of inflammatory bowel disease: the evolving model.

tions (HLA-region, TNFSF15/TL1A, IRF5, PTPN2, PTPN22, NKX2-3, IL-12B, IL-18RAP, MST1). ${ }^{94}$ NOD2/CARD15 mutations can also cause abnormal development of Peyer's patches as well as deficient defensin production by Paneth cells, ${ }^{95}$ both of which can lead to defective clearance of organisms. Interestingly, a recent study has demonstrated that $\mathrm{CD}$ patients that are mutant for NOD2 show ineffective recognition of MAP. ${ }^{96}$ Additionally, it has been shown that down-regulation of the autophagy gene, $I R G M$, alterations in which are also linked to the pathogenesis of $\mathrm{CD}$, leads to prolonged survival of MAP in macrophages. ${ }^{97}$ Moreover the CD-associated NOD2 mutations are also associated with increased susceptibility to infection with M. leprae. ${ }^{98}$ MAP is present in the human food chain, in meat and milk ${ }^{99}$ but the presence of MAP DNA in CD patient samples is not sufficient to establish MAP as a causative agent. Moreover, therapies targeted at MAP do not produce a cure. ${ }^{100,101}$ Nevertheless, in vitro studies have shown that MAP potentially benefits from genetic mutations that are known to predispose CD. ${ }^{96,97}$ A novel model of $\mathrm{CD}$ has been proposed ${ }^{78}$ in which MAP, a low virulence organism, infects a large proportion of the population through its presence in the food chain, but only causes/exacerbates disease in those individuals that are genetically susceptible, for example, those that have dysfunctional IFN $\gamma$ activity that would fail to properly modulate transition between the specific and innate immune system.

\section{ULCERATIVE COLITIS AND BACTERIA}

UC is characterised by ulcers present in the colon and bloody diarrhoea. Indirect evidence for the involvement of microorganisms, includes the presence of mucosal neutrophil infiltration, which could be caused by the uptake of luminal antigens ${ }^{102}$ and the activation of $\mathrm{NF} \kappa \mathrm{B}(\mathrm{NF} \kappa \mathrm{B})$ as an early event ${ }^{103}$ which is consistent with surface bacterial interaction. Studies by Kotlowski et al. ${ }^{15}$ and Swidsinski et al. ${ }^{104}$ both showed an increase in the num- 
ber of E. coli isolated from UC patients mucosa however, levels were lower than that for $\mathrm{CD}$. Unlike $\mathrm{CD}$ there is no evidence that bacteria, and specifically E. coli, isolated from UC patients invade the mucosa. It seems more likely that bacteria or bacterial components interact with surface epithelial cells to induce an inflammatory response, e.g., as a consequence of IL8 release and consequent neutrophil recruitment.

Several studies have linked acute bacterial enteritis with the onset or exacerbation of UC with causative agents including but not exclusively, Clostridium difficile, ${ }^{11,105,106}$ Yersinia enterocolitica, ${ }^{107,108}$ Campylobacter jejuni ${ }^{109}$ and Salmonella spp. ${ }^{109-112}$ It has been suggested that infection with Campylobacter jejuni may facilitate invasion of the colonic epithelia by non-invasive commensal organisms ${ }^{113}$ by either a paracellular or transcellular mechanism which is strain dependent. ${ }^{114,115}$ C. jejuni RM1221 is able to disrupt epithelial tight junctions, increasing paracellular permeability ultimately allowing non-invasive organisms to translocate through the epithelial layer. Furthermore, repositioning of TLRs increases the frequency of interaction with the microbiota, leading to release of $\mathrm{NF} \kappa \mathrm{B}$ and thus inflammation. Conversely, another strain of $C$. jejuni induces transcellular translocation by the use of lipid rafts, another process that leads to interaction with NOD2 receptors and release of NF $\kappa \mathrm{B}$. In keeping with this it has been shown that commensal organisms formed "microcolonies" in colitis patients. ${ }^{116}$ Further evidence for the involvement of the microbiota comes from anecdotal evidence that colitis can be improved by the use of fecal bacteriotherapy, sometimes known as "faecal transplant."117 Probiotic therapy in active colitis has however been disappointing. ${ }^{118}$

Impairment of the mucosal barrier, either due to genetic alterations or as the result of concurrent pathogen infection, may affect interactions between the epithelium and bacterial components. Thus the flagellin receptor toll-like receptor 5 (TLR5), is located primarily on the basolateral aspect of surface epithelial cells and only becomes accessible to bacterial flagellin once the mucosal barrier has been weakened. This was strikingly demonstrated in an animal model where prior treatment of mice with oral dextran sulphate coupled with rectal instillation of bacterial flagellin led to a fatal colitis. ${ }^{119}$

The relationship between IBD and $C$. difficile is complex. There is little evidence to support a direct role for $C$. difficile in induction of relapse but $C$. difficile carriage is substantially increased in IBD patients, even without prior antibiotic treatment. ${ }^{120-124}$ Ulcerative colitis patients infected with $C$. difficile ${ }^{123}$ tend to have a more protracted illness featuring a marked acute phase response associated with a relatively high serum $\mathrm{C}$ reactive protein. The cause for the high $C$. difficile carriage rate is unknown however the dysbiosis associated with IBD may contribute to patient susceptibility. Furthermore, reduced expression of human alpha-defensins in IBD patients may also play a role. ${ }^{125}$ Since asymptomatic carriage of $C$. difficile exists in IBD patients ${ }^{105}$ the main practical implication is that all patients with relapse of IBD should have a fecal sample checked for $C$. difficile, especially those receiving immunosuppressant therapy since this is known to be a risk factor for infection. ${ }^{121}$

\section{SUMMARY}

Modern molecular techniques are giving us a much more robust knowledge of the mucosal and faecal microbiota in inflammatory bowel disease. There is now strong evidence to support the hypothesis that Crohn's disease develops as a result of invasion of the mucosa by live bacteria with defective clearance by the innate immune system and consequent replication of bacteria within mac-

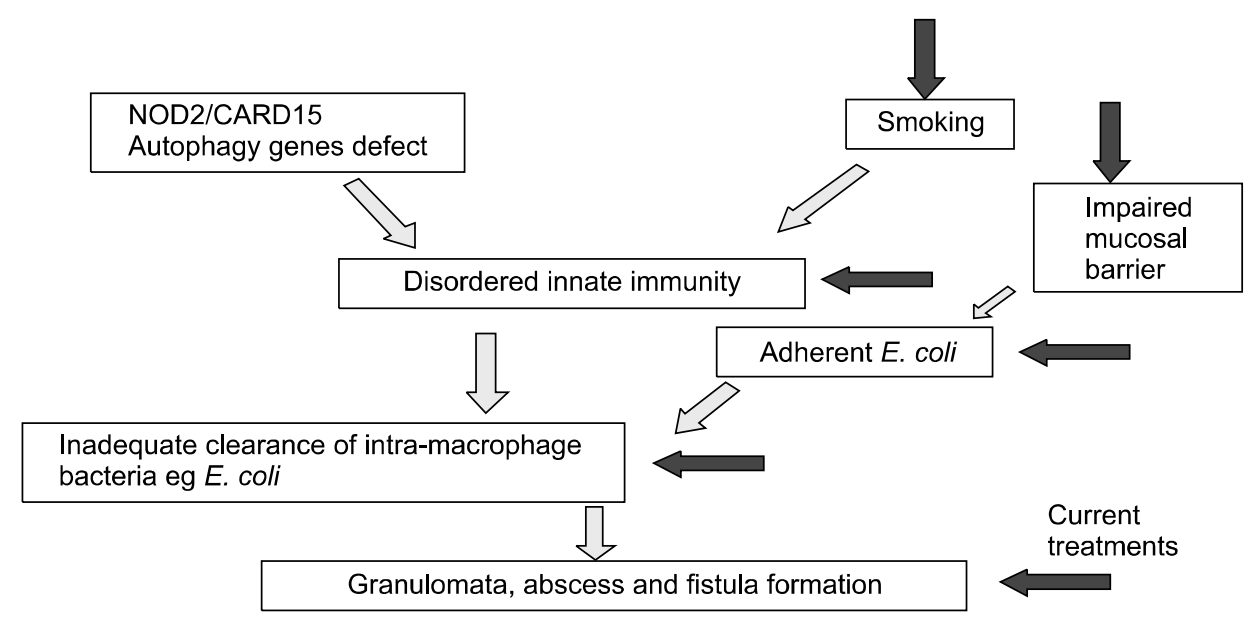

Fig. 3. A model for the pathogenesis of Crohn's disease in which mucosal invasion by bacteria, perhaps particularly E. coli, occurs as a result of impairments in the mucosal barrier and/or the innate immune system. $\leftarrow$ denote possible therapeutic targets. 


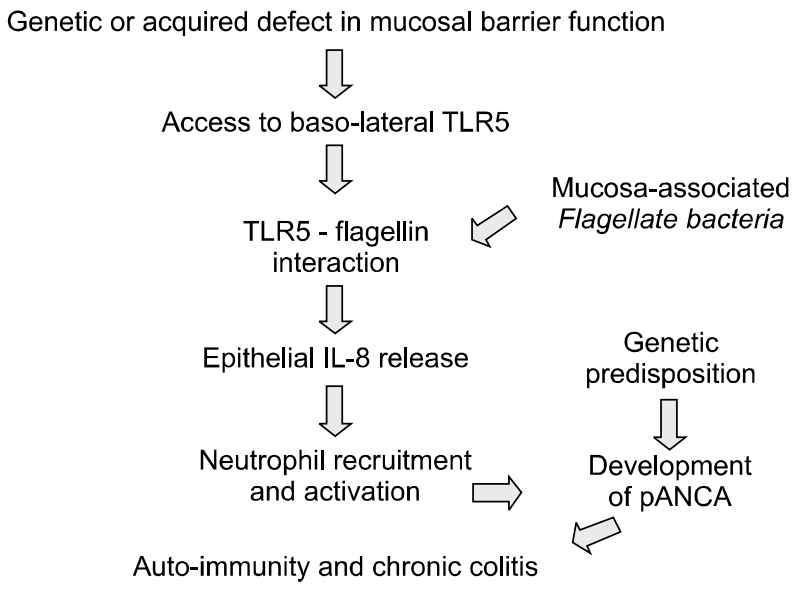

Fig. 4. A model for bacterial involvement in pathogenesis of ulcerative colitis (Adapted with permission from Rhodes JM. Gut 2007;56:610-612. $\left.{ }^{133}\right)$.

rophages (Fig. 3). In ulcerative colitis there is little evidence of invasion by whole bacteria and more to support the hypothesis that a defective mucosal barrier may lead to increased interaction between bacterial components, such as flagellin or DNA, and basolateral receptors with inflammation as a consequence (Fig. 4).

\section{ACKNOWLEDGEMENTS}

Work in the authors laboratory is supported by grants from the National Association for Colitis and Crohn's Disease (NACC), National Institute of Health Research (NIHR), Wellcome Trust and Provexis Plc, UK.

\section{REFERENCES}

1. Suau A, Bonnet R, Sutren $\mathrm{M}$, et al. Direct analysis of genes encoding 16S rRNA from complex communities reveals many novel molecular species within the human gut. Appl Environ Microbiol 1999;65:4799-4807.

2. Sokol H, Pigneur B, Watterlot L, et al. Faecalibacterium prausnitzii is an anti-inflammatory commensal bacterium identified by gut microbiota analysis of Crohn disease patients. Proc Natl Acad Sci U S A 2008;105:16731-16736.

3. Willing B, Halfvarson J, Dicksved J, et al. Twin studies reveal specific imbalances in the mucosa-associated microbiota of patients with ileal Crohn's disease. Inflamm Bowel Dis 2009; 15:653-660.

4. Sokol H, Seksik P, Furet JP, et al. Low counts of Faecalibacterium prausnitzii in colitis microbiota. Inflamm Bowel Dis 2009;15:1183-1189.

5. Ott SJ, Kühbacher T, Musfeldt M, et al. Fungi and inflammatory bowel diseases: alterations of composition and diversity. Scand J Gastroenterol 2008;43:831-841.

6. Mpofu CM, Campbell BJ, Subramanian S, et al. Microbial mannan inhibits bacterial killing by macrophages: a possible pathogenic mechanism for Crohn's disease. Gastroent- erology 2007;133:1487-1498.

7. Martin HM, Campbell BJ, Hart CA, et al. Enhanced Escherichia coli adherence and invasion in Crohn's disease and colon cancer. Gastroenterology 2004;127:80-93.

8. Swidsinski A, Weber J, Loening-Baucke V, Hale LP, Lochs H. Spatial organization and composition of the mucosal flora in patients with inflammatory bowel disease. J Clin Microbiol 2005;43:3380-3389.

9. Macfarlane S, Furrie E, Cummings JH, Macfarlane GT. Chemotaxonomic analysis of bacterial populations colonizing the rectal mucosa in patients with ulcerative colitis. Clin Infect Dis 2004;38:1690-1699.

10. Tabaqchali S, O'Donoghue DP, Bettelheim KA. Escherichia coli antibodies in patients with inflammatory bowel disease. Gut 1978;19:108-113.

11. Weber P, Koch M, Heizmann WR, Scheurlen M, Jenss H, Hartmann F. Microbic superinfection in relapse of inflammatory bowel disease. J Clin Gastroenterol 1992;14: 302-308.

12. Darfeuille-Michaud A, Neut C, Barnich N, et al. Presence of adherent Escherichia coli strains in ileal mucosa of patients with Crohn's disease. Gastroenterology 1998;115: 1405-1413.

13. Boudeau J, Glasser AL, Masseret E, Joly B, DarfeuilleMichaud A. Invasive ability of an Escherichia coli strain isolated from the ileal mucosa of a patient with Crohn's disease. Infect Immun 1999;67:4499-4509.

14. Subramanian S, Rhodes JM, Hart CA, et al. Characterization of epithelial IL-8 response to inflammatory bowel disease mucosal E. coli and its inhibition by mesalamine. Inflamm Bowel Dis 2008;14:162-175.

15. Kotlowski R, Bernstein CN, Sepehri S, Krause DO. High prevalence of Escherichia coli belonging to the $\mathrm{B} 2+\mathrm{D}$ phylogenetic group in inflammatory bowel disease. Gut 2007; 56:669-675.

16. Bringer MA, Glasser AL, Tung CH, Méresse S, DarfeuilleMichaud A. The Crohn's disease-associated adherent-invasive Escherichia coli strain LF82 replicates in mature phagolysosomes within J774 macrophages. Cell Microbiol 2006;8:471-484.

17. Barnich N, Bringer MA, Claret L, Darfeuille-Michaud A. Involvement of lipoprotein $\mathrm{NlpI}$ in the virulence of adherent invasive Escherichia coli strain LF82 isolated from a patient with Crohn's disease. Infect Immun 2004;72:24842493.

18. Rolhion N, Barnich N, Claret L, Darfeuille-Michaud A. Strong decrease in invasive ability and outer membrane vesicle release in Crohn's disease-associated adherent-invasive Escherichia coli strain LF82 with the yfgL gene deleted. J Bacteriol 2005; 187:2286-2296.

19. Simpson KW, Dogan B, Rishniw M, et al. Adherent and invasive Escherichia coli is associated with granulomatous colitis in boxer dogs. Infect Immun 2006;74:4778-4792.

20. Rolhion N, Darfeuille-Michaud A. Adherent-invasive Escherichia coli in inflammatory bowel disease. Inflamm Bowel Dis 2007;13:1277-1283.

21. Glasser AL, Boudeau J, Barnich N, Perruchot MH, Colombel JF, Darfeuille-Michaud A. Adherent invasive Escherichia coli strains from patients with Crohn's disease survive and replicate within macrophages without inducing host cell death. Infect Immun 2001;69:5529-5537. 
22. Lodes MJ, Cong Y, Elson CO, et al. Bacterial flagellin is a dominant antigen in Crohn disease. J Clin Invest 2004; 113:1296-1306

23. Miller H, Zhang J, Kuolee R, Patel GB, Chen W. Intestinal M cells: the fallible sentinels? World J Gastroenterol 2007;13:1477-1486.

24. Siebers A, Finlay BB. M cells and the pathogenesis of mucosal and systemic infections. Trends Microbiol 1996;4:2229.

25. Shikuwa $\mathrm{S}$, Isomoto $\mathrm{H}$, Mizuta $\mathrm{Y}$, Suematsu $\mathrm{T}$, Ito $\mathrm{M}$, Kohno S. Magnifying videoendoscopic findings of Peyer's patches in the terminal ileum of Crohn's disease. Gut 2007;56:894-895.

26. Fujimura Y, Kamoi R, Iida M. Pathogenesis of aphthoid ulcers in Crohn's disease: correlative findings by magnifying colonoscopy, electron microscopy, and immunohistochemistry. Gut 1996;38:724-732.

27. Ishimoto H, Isomoto H, Shikuwa S. Endoscopic identification of Peyer's patches of the terminal ileum in a patient with Crohn's disease. World J Gastroenterol 2004; 10:2767-2768.

28. Garside P, Millington O, Smith KM. The anatomy of mucosal immune responses. Ann N Y Acad Sci 2004;1029: 9-15.

29. Kernéis S, Bogdanova A, Kraehenbuhl JP, Pringault E. Conversion by Peyer's patch lymphocytes of human enterocytes into $\mathrm{M}$ cells that transport bacteria. Science 1997;277:949-952.

30. Giannasca PJ, Giannasca KT, Falk P, Gordon JI, Neutra MR. Regional differences in glycoconjugates of intestinal $\mathrm{M}$ cells in mice: potential targets for mucosal vaccines. Am J Physiol 1994;267(6 Pt 1):G1108-G1121.

31. Borghesi C, Taussig MJ, Nicoletti C. Rapid appearance of $\mathrm{M}$ cells after microbial challenge is restricted at the periphery of the follicle-associated epithelium of Peyer's patch. Lab Invest 1999;79:1393-1401.

32. Gebert A, Steinmetz I, Fassbender S, Wendlandt KH. Antigen transport into Peyer's patches: increased uptake by constant numbers of M cells. Am J Pathol 2004;164:65-72.

33. Owen RL, Pierce NF, Apple RT, Cray WC Jr. M cell transport of Vibrio cholerae from the intestinal lumen into Peyer's patches: a mechanism for antigen sampling and for microbial transepithelial migration. J Infect Dis 1986;153: 1108-1118

34. Walker RI, Schmauder-Chock EA, Parker JL, Burr D. Selective association and transport of Campylobacter jejuni through M cells of rabbit Peyer's patches. Can J Microbiol 1988;34:1142-1147.

35. Golovkina TV, Shlomchik M, Hannum L, Chervonsky A. Organogenic role of B lymphocytes in mucosal immunity. Science 1999;286:1965-1968.

36. Karapetian O, Shakhov AN, Kraehenbuhl JP, Acha-Orbea H. Retroviral infection of neonatal Peyer's patch lymphocytes: the mouse mammary tumor virus model. J Exp Med 1994;180:1511-1516.

37. Landsverk T. Cryptosporidiosis and the follicle-associated epithelium over the ileal Peyer's patch in calves. Res Vet Sci 1987;42:299-306.

38. Man AL, Lodi F, Bertelli E, et al. Macrophage migration inhibitory factor plays a role in the regulation of microfold (M) cell-mediated transport in the gut. J Immunol
2008;181:5673-5680.

39. Phillips AD, Navabpour S, Hicks S, Dougan G, Wallis T, Frankel G. Enterohaemorrhagic Escherichia coli O157:H7 target Peyer's patches in humans and cause attaching/effacing lesions in both human and bovine intestine. Gut 2000;47:377-381.

40. Beaulieu JF. Differential expression of the VLA family of integrins along the crypt-villus axis in the human small intestine. J Cell Sci 1992;102(Pt 3):427-436.

41. Clark MA, Hirst BH, Jepson MA. M-cell surface betal integrin expression and invasin-mediated targeting of Yersinia pseudotuberculosis to mouse Peyer's patch $\mathrm{M}$ cells. Infect Immun 1998;66:1237-1243.

42. Schulte R, Kerneis S, Klinke S. Translocation of Yersinia entrocolitica across reconstituted intestinal epithelial monolayers is triggered by Yersinia invasin binding to betal integrins apically expressed on M-like cells. Cell Microbiol 2000;2:173-185.

43. Hamzaoui N, Kernéis S, Caliot E, Pringault E. Expression and distribution of betal integrins in in vitro-induced $M$ cells: implications for Yersinia adhesion to Peyer's patch epithelium. Cell Microbiol 2004;6:817-828.

44. Isberg RR, Leong JM. Multiple beta 1 chain integrins are receptors for invasin, a protein that promotes bacterial penetration into mammalian cells. Cell 1990;60:861-871.

45. Hase K, Kawano K, Nochi T, et al. Uptake through glycoprotein 2 of $\mathrm{FimH}(+)$ bacteria by $\mathrm{M}$ cells initiates mucosal immune response. Nature 2009;462:226-230.

46. Roggenbuck D, Hausdorf G, Martinez-Gamboa L, et al. Identification of GP2, the major zymogen granule membrane glycoprotein, as the autoantigen of pancreatic antibodies in Crohn's disease. Gut 2009;58:1620-1628.

47. Kim J, Hegde M, Jayaraman A. Co-culture of epithelial cells and bacteria for investigating host-pathogen interactions. Lab Chip 2010;10:43-50.

48. Söderholm JD, Hedman L, Artursson P, et al. Integrity and metabolism of human ileal mucosa in vitro in the Ussing chamber. Acta Physiol Scand 1998;162:47-56.

49. Keita AV, Salim SY, Jiang T, et al. Increased uptake of non-pathogenic E. coli via the follicle-associated epithelium in longstanding ileal Crohn's disease. J Pathol 2008; 215:135-144.

50. Allen LA. Mechanisms of pathogenesis: evasion of killing by polymorphonuclear leukocytes. Microbes Infect 2003;5: 1329-1335.

51. Marks DJ, Harbord MW, MacAllister R, et al. Defective acute inflammation in Crohn's disease: a clinical investigation. Lancet 2006;367:668-678.

52. Smith AM, Rahman FZ, Hayee B, et al. Disordered macrophage cytokine secretion underlies impaired acute inflammation and bacterial clearance in Crohn's disease. J Exp Med 2009;206:1883-1897.

53. Aderem A. Phagocytosis and the inflammatory response. J Infect Dis 2003;187 Suppl 2:S340-S345.

54. Liu Y, van Kruiningen $\mathrm{HJ}$, West $\mathrm{AB}$, Cartun RW, Cortot A, Colombel JF. Immunocytochemical evidence of Listeria, Escherichia coli, and Streptococcus antigens in Crohn's disease. Gastroenterology 1995;108:1396-1404.

55. Ryan P, Kelly RG, Lee G, et al. Bacterial DNA within granulomas of patients with Crohn's disease--detection by laser capture microdissection and PCR. Am J Gastroenterol 
2004;99:1539-1543.

56. Subramanian S, Roberts CL, Hart CA, et al. Replication of colonic Crohn's disease mucosal Escherichia coli isolates within macrophages and their susceptibility to antibiotics. Antimicrob Agents Chemother 2008;52:427-434.

57. Kruis W. Review article: antibiotics and probiotics in inflammatory bowel disease. Aliment Pharmacol Ther 2004; 20 Suppl 4:75-78.

58. Sartor RB. Targeting enteric bacteria in treatment of inflammatory bowel diseases: why, how, and when. Curr Opin Gastroenterol 2003;19:358-365.

59. Colombel JF, Cortot A, van Kruiningen HJ. Antibiotics in Crohn's disease. Gut 2001;48:647.

60. Selby W, Pavli P, Crotty B, et al. Two-year combination antibiotic therapy with clarithromycin, rifabutin, and clofazimine for Crohn's disease. Gastroenterology 2007;132: 2313-2319.

61. Rahimi R, Nikfar S, Rezaie A, Abdollahi M. A meta-analysis of broad-spectrum antibiotic therapy in patients with active Crohn's disease. Clin Ther 2006;28:1983-1988.

62. Leiper K, Martin K, Ellis A, Watson AJ, Morris AI, Rhodes JM. Clinical trial: randomized study of clarithromycin versus placebo in active Crohn's disease. Aliment Pharmacol Ther 2008;27:1233-1239.

63. Singh S, Graff LA, Bernstein CN. Do NSAIDs, antibiotics, infections, or stress trigger flares in IBD? Am J Gastroenterol 2009;104:1298-1313.

64. Aronson M, Medalia O, Schori L, Mirelman D, Sharon N, Ofek I. Prevention of colonization of the urinary tract of mice with Escherichia coli by blocking of bacterial adherence with methyl alpha-D-mannopyranoside. J Infect Dis 1979;139:329-332.

65. Rabbani GH, Ahmed S, Hossain I, et al. Green banana reduces clinical severity of childhood shigellosis: a double-blind, randomized, controlled clinical trial. Pediatr Infect Dis J 2009;28:420-425.

66. Rabbani GH, Teka T, Zaman B, Majid N, Khatun M, Fuchs GJ. Clinical studies in persistent diarrhea: dietary management with green banana or pectin in Bangladeshi children. Gastroenterology 2001;121:554-560.

67. Sharon N, Ofek I. Fighting infectious diseases with inhibitors of microbial adhesion to host tissues. Crit Rev Food Sci Nutr 2002;42(3 Suppl):267-272.

68. Geier MS, Butler RN, Howarth GS. Inflammatory bowel disease: current insights into pathogenesis and new therapeutic options: probiotics, prebiotics and synbiotics. Int J Food Microbiol 2007;115:1-11.

69. Ryan K, Ray C, Sherris JC. Sherris medical microbiology. 4th ed. New York: McGraw Hill, 2004.

70. Dalziel TK. Chronic interstitial enteritis. Br Med J 1913; 2:1068-1070.

71. Nacy CA, Buckley M. Mycobacterium avium paratuberculosis: infrequent human pathogen or public health threat? Washington, DC: American Academy of Microbiology, 2008.

72. Chamberlin WM, Naser SA. Integrating theories of the etiology of Crohn's disease. On the etiology of Crohn's disease: questioning the hypotheses. Med Sci Monit 2006; 12:RA27-RA33.

73. Naser SA, Ghobrial G, Romero C, Valentine JF. Culture of Mycobacterium avium subspecies paratuberculosis from the blood of patients with Crohn's disease. Lancet 2004;364:
1039-1044.

74. Bull TJ, McMinn EJ, Sidi-Boumedine K, et al. Detection and verification of Mycobacterium avium subsp. paratuberculosis in fresh ileocolonic mucosal biopsy specimens from individuals with and without Crohn's disease. J Clin Microbiol 2003;41:2915-2923.

75. Englund S, Bölske G, Johansson KE. An IS900-like sequence found in a Mycobacterium sp. other than Mycobacterium avium subsp. paratuberculosis. FEMS Microbiol Lett 2002;209:267-271.

76. Buergelt CD, Williams JE. Nested PCR on blood and milk for the detection of Mycobacterium avium subsp paratuberculosis DNA in clinical and subclinical bovine paratuberculosis. Aust Vet J 2004;82:497-503.

77. Bentley RW, Keenan JI, Gearry RB, Kennedy MA, Barclay ML, Roberts RL. Incidence of Mycobacterium avium subspecies paratuberculosis in a population-based cohort of patients with Crohn's disease and control subjects. Am J Gastroenterol 2008;103:1168-1172.

78. Juste RA, Elguezabal N, Pavón A, et al. Association between Mycobacterium avium subsp. paratuberculosis DNA in blood and cellular and humoral immune response in inflammatory bowel disease patients and controls. Int J Infect Dis 2009;13:247-254.

79. Kirkwood CD, Wagner J, Boniface K, et al. Mycobacterium avium subspecies paratuberculosis in children with early-onset Crohn's disease. Inflamm Bowel Dis 2009;15: 1643-1655.

80. Feller M, Huwiler K, Stephan R, et al. Mycobacterium avium subspecies paratuberculosis and Crohn's disease: a systematic review and meta-analysis. Lancet Infect Dis 2007;7:607-613.

81. Abubakar I, Myhill D, Aliyu SH, Hunter PR. Detection of Mycobacterium avium subspecies paratuberculosis from patients with Crohn's disease using nucleic acid-based techniques: a systematic review and meta-analysis. Inflamm Bowel Dis 2008;14:401-410.

82. Naser SA, Hulten K, Shafran I, Graham DY, El-Zaatari FA. Specific seroreactivity of Crohn's disease patients against p35 and p36 antigens of M. avium subsp. paratuberculosis. Vet Microbiol 2000;77:497-504.

83. Chacon O, Bermudez LE, Barletta RG. Johne's disease, inflammatory bowel disease, and Mycobacterium paratuberculosis. Annu Rev Microbiol 2004;58:329-363.

84. Olsen I, Tollefsen S, Aagaard C, et al. Isolation of Mycobacterium avium subspecies paratuberculosis reactive CD4 $\mathrm{T}$ cells from intestinal biopsies of Crohn's disease patients. PLoS One 2009;4:e5641.

85. Basler T, Geffers R, Weiss S, Valentin-Weigand P, Goethe R. Mycobacterium avium subspecies induce differential expression of pro-inflammatory mediators in a murine macrophage model: evidence for enhanced pathogenicity of Mycobacterium avium subspecies paratuberculosis. Immunobiology 2008;213:879-888.

86. Shin AR, Kim HJ, Cho SN, et al. Identification of seroreactive proteins in the culture filtrate antigen of Mycobacterium avium ssp. paratuberculosis human isolates to sera from Crohn's disease patients. FEMS Immunol Med Microbiol 2009;58:128-137.

87. Peeters M, Joossens S, Vermeire S, Vlietinck R, Bossuyt X, Rutgeerts P. Diagnostic value of anti-Saccharomyces cer- 
evisiae and antineutrophil cytoplasmic autoantibodies in inflammatory bowel disease. Am J Gastroenterol 2001;96: 730-734.

88. Quinton JF, Sendid B, Reumaux D, et al. Anti-Saccharomyces cerevisiae mannan antibodies combined with antineutrophil cytoplasmic autoantibodies in inflammatory bowel disease: prevalence and diagnostic role. Gut 1998; 42:788-791.

89. Sendid B, Colombel JF, Jacquinot PM, et al. Specific antibody response to oligomannosidic epitopes in Crohn's disease. Clin Diagn Lab Immunol 1996;3:219-226.

90. Young M, Davies MJ, Bailey D, et al. Characterization of oligosaccharides from an antigenic mannan of Saccharomyces cerevisiae. Glycoconj J 1998;15:815-822.

91. Standaert-Vitse A, Jouault T, Vandewalle $P$, et al. Candida albicans is an immunogen for anti-Saccharomyces cerevisiae antibody markers of Crohn's disease. Gastroenterology 2006;130:1764-1775.

92. Michell SL, Whelan AO, Wheeler PR, et al. The MPB83 antigen from Mycobacterium bovis contains O-linked mannose and $(1 \rightarrow 3)$-mannobiose moieties. J Biol Chem 2003;278:16423-16432.

93. Guerardel Y, Maes E, Elass E, et al. Structural study of lipomannan and lipoarabinomannan from Mycobacterium chelonae. Presence of unusual components with alpha 1,3-mannopyranose side chains. J Biol Chem 2002;277: 30635-30648.

94. Van Limbergen J, Wilson DC, Satsangi J. The genetics of Crohn's disease. Annu Rev Genomics Hum Genet 2009; 10:89-116.

95. Barreau F, Meinzer U, Chareyre F, et al. CARD15/NOD2 is required for Peyer's patches homeostasis in mice. PLoS One 2007;2:e523.

96. Ferwerda G, Kullberg BJ, de Jong DJ, et al. Mycobacterium paratuberculosis is recognized by Toll-like receptors and NOD2. J Leukoc Biol 2007;82:1011-1018.

97. Singh SB, Davis AS, Taylor GA, Deretic V. Human IRGM induces autophagy to eliminate intracellular mycobacteria. Science 2006:313:1438-1441.

98. Schurr E, Gros P. A common genetic fingerprint in leprosy and Crohn's disease? N Engl J Med 2009;361:26662668.

99. Streeter RN, Hoffsis GF, Bech-Nielsen S, Shulaw WP, Rings DM. Isolation of Mycobacterium paratuberculosis from colostrum and milk of subclinically infected cows. Am J Vet Res 1995;56:1322-1324.

100. Thomas GA, Rhodes J, Green JT. Inflammatory bowel disease and smoking--a review. Am J Gastroenterol 1998; 93:144-149.

101. Sartor RB. Does Mycobacterium avium subspecies paratuberculosis cause Crohn's disease? Gut 2005;54:896-898.

102. Gitter AH, Wullstein F, Fromm M, Schulzke JD. Epithelial barrier defects in ulcerative colitis: characterization and quantification by electrophysiological imaging. Gastroenterology 2001;121:1320-1328.

103. Bodger K, Halfvarson J, Dodson AR, et al. Altered colonic glycoprotein expression in unaffected monozygotic twins of inflammatory bowel disease patients. Gut 2006;55:973977.

104. Swidsinski A, Ladhoff A, Pernthaler A, et al. Mucosal flora in inflammatory bowel disease. Gastroenterology
2002;122:44-54.

105. Clayton EM, Rea MC, Shanahan F, et al. The vexed relationship between Clostridium difficile and inflammatory bowel disease: an assessment of carriage in an outpatient setting among patients in remission. Am J Gastroenterol 2009;104:1162-1169.

106. Freeman HJ. Recent developments on the role of Clostridium difficile in inflammatory bowel disease. World J Gastroenterol 2008;14:2794-2796.

107. Saebo A, Vik E, Lange OJ, Matuszkiewicz L. Inflammatory bowel disease associated with Yersinia enterocolitica O:3 infection. Eur J Intern Med 2005;16:176-182.

108. Kallinowski F, Wassmer A, Hofmann MA, et al. Prevalence of enteropathogenic bacteria in surgically treated chronic inflammatory bowel disease. Hepatogastroenterology 1998;45:1552-1558.

109. Siegal D, Syed F, Hamid N, Cunha BA. Campylobacter jejuni pancolitis mimicking idiopathic ulcerative colitis. Heart Lung 2005;34:288-290.

110. Karaoglu AO, Yukselen V, Ertem GT, Erkus M. Salmonellosis and ulcerative colitis. A causal relationship or just a coincidence. Saudi Med J 2004;25:1486-1488.

111. Gradel KO, Nielsen HL, Schønheyder HC, Ejlertsen T, Kristensen B, Nielsen H. Increased short- and long-term risk of inflammatory bowel disease after salmonella or campylobacter gastroenteritis. Gastroenterology 2009;137: 495-501.

112. Ternhag A, Törner A, Svensson A, Ekdahl K, Giesecke J. Short- and long-term effects of bacterial gastrointestinal infections. Emerg Infect Dis 2008;14:143-148.

113. Kleessen B, Kroesen AJ, Buhr HJ, Blaut M. Mucosal and invading bacteria in patients with inflammatory bowel disease compared with controls. Scand J Gastroenterol 2002;37:1034-1041.

114. Lamb-Rosteski JM, Kalischuk LD, Inglis GD, Buret AG. Epidermal growth factor inhibits Campylobacter jejuni-induced claudin-4 disruption, loss of epithelial barrier function, and Escherichia coli translocation. Infect Immun 2008; 76:3390-3398.

115. Kalischuk LD, Inglis GD, Buret AG. Campylobacter jejuni induces transcellular translocation of commensal bacteria via lipid rafts. Gut Pathog 2009;1:2.

116. Macfarlane GT, Furrie E, Macfarlane S. Bacterial milieu and mucosal bacteria in ulcerative colitis. Novartis Found Symp 2004;263:57-64.

117. Borody TJ, Warren EF, Leis S, Surace R, Ashman O. Treatment of ulcerative colitis using fecal bacteriotherapy. J Clin Gastroenterol 2003;37:42-47.

118. Shanahan F. Probiotics in inflamatory bowel disease. Gut 2001;48:609.

119. Rhee SH, Im E, Riegler M, Kokkotou E, O'brien M, Pothoulakis C. Pathophysiological role of Toll-like receptor 5 engagement by bacterial flagellin in colonic inflammation. Proc Natl Acad Sci U S A 2005;102:1361013615.

120. Schneeweiss S, Korzenik J, Solomon DH, Canning C, Lee $\mathrm{J}$, Bressler B. Infliximab and other immunomodulating drugs in patients with inflammatory bowel disease and the risk of serious bacterial infections. Aliment Pharmacol Ther 2009;30:253-264.

121. Issa $M$, Vijayapal $A$, Graham $M B$, et al. Impact of 
Clostridium difficile on inflammatory bowel disease. Clin Gastroenterol Hepatol 2007;5:345-351.

122. Nguyen GC, Sam J. Rising prevalence of venous thromboembolism and its impact on mortality among hospitalized inflammatory bowel disease patients. Am J Gastroenterol 2008;103:2272-2280.

123. Ricciardi R, Ogilvie JW Jr, Roberts PL, Marcello PW, Concannon TW, Baxter NN. Epidemiology of Clostridium difficile colitis in hospitalized patients with inflammatory bowel diseases. Dis Colon Rectum 2009;52:40-45.

124. Rodemann JF, Dubberke ER, Reske KA, Seo da H, Stone $\mathrm{CD}$. Incidence of Clostridium difficile infection in inflammatory bowel disease. Clin Gastroenterol Hepatol 2007;5:339-344.

125. Ramasundara M, Leach ST, Lemberg DA, Day AS. Defensins and inflammation: the role of defensins in inflammatory bowel disease. J Gastroenterol Hepatol 2009; 24:202-208.

126. Knight P, Campbell BJ, Rhodes JM. Host-bacteria interaction in inflammatory bowel disease. Br Med Bull 2008; 88:95-113.

127. Ruiz-Palacios GM, Cervantes LE, Ramos P, Chavez-Munguia B, Newburg DS. Campylobacter jejuni binds intestinal $\mathrm{H}(\mathrm{O})$ antigen (Fuc alpha 1, 2Gal beta 1,
4GlcNAc), and fucosyloligosaccharides of human milk inhibit its binding and infection. J Biol Chem 2003;278: 14112-14120.

128. Goldhar J, Zilberberg A, Ofek I. Infant mouse model of adherence and colonization of intestinal tissues by enterotoxigenic strains of Escherichia coli isolated from humans. Infect Immun 1986;52:205-208.

129. Mouricout M, Petit JM, Carias JR, Julien R. Glycoprotein glycans that inhibit adhesion of Escherichia coli mediated by K99 fimbriae: treatment of experimental colibacillosis. Infect Immun 1990;58:98-106.

130. Mouricout M. Swine and cattle enterotoxigenic Escherichia coli-mediated diarrhea. Development of therapies based on inhibition of bacteria-host interactions. Eur J Epidemiol 1991;7:588-604.

131. Parker P, Sando L, Pearson R, Kongsuwan K, Tellam RL, Smith S. Bovine Muc1 inhibits binding of enteric bacteria to Caco-2 cells. Glycoconj J 2009;27:89-97.

132. Mysore JV, Wigginton T, Simon PM, Zopf D, HemanAckah LM, Dubois A. Treatment of Helicobacter pylori infection in rhesus monkeys using a novel antiadhesion compound. Gastroenterology 1999;117:1316-1325.

133. Rhodes JM. The role of Escherichia coli in inflammatory bowel disease. Gut 2007;56:610-612. 